\title{
Posterior Annular Ligament
}

National Cancer Institute

\section{Source}

National Cancer Institute. Posterior Annular Ligament. NCI Thesaurus. Code C33348.

A lig ament that surrounds the head of the radius. 